\title{
PESTS OF FIELD CROPS
}

F. G. W. Jones and Margaret G. Jones

'This book should be invaluable to students in university departments of agriculture and agricultural colleges.' Journal of the Association of Agriculture

'A remarkable volume which, in a commendably short text, covers all the major agricultural pests found in Britain.' The Guardian

50s. net

\section{THE MECHANISM OF HEREDITY}

H. L. F. Whitehouse

An excellent synthesis of the evidence for all current beliefs concerning the mechanism of heredity. This aspect of genetics occupies a central position in modern biology and the book is therefore a most important addition to the literature.

55s. net

\section{ELEMENTARY MICROTECHNIQUE}

THIRD EDITION

H. Alan Peacock

In this, the third edition of the well-known textbook, the author has added new material and techniques that have been perfected since the second edition, including the Feulgen cytological techniques and notes on embedding by the collodion, freezing, gelatin and resin methods. He has also revised and rationalised the arrangement of much material to maintain the book's usefulness as a concise and handy reference book.

45s. net

\section{EDWARD ARNOLD}

41 Maddox Street, London, W. 1

FULL PARTICULARS OF THE

\section{JOURNALS}

PUBLISHED BY THE

CAMBRIDGE

UNIVERSITY PRESS

MAY BE HAD FROM

THE MANAGER

CAMBRIDGE UNIVERSITY PRESS

BENTLEY HOUSE

200 EUSTON ROAD

LONDON, N.W.1

\section{CROP SCIENCE}

Crop breeders, plant geneticists and physiologists, and workers in related areas will find Crop Science a source of valuable articles in their branches of science. This bimonthly journal carries reports of research in the genetics, physiology, ecology, breeding and management of field crops, turfgrasses, pastures and ranges, and in seed technology. It is published by the Crop Science Society of America.

$\$ 16.00$ per year in U.S. and Canada. $\$ 17.00$ per year elsewhere.

Crop Science Society of America 677 S. Segoe Rd,

Madison, Wisconsin, U.S.A., 53711 
EVERTt, G. C. and Jury, K. E. Effects of sex and gonadectomy on the growth and development of Southdown $\times$ Romney Cross lambs. Part I. Effects on live-weight growth and components of live weight. (With Five Text-figures)

EVERIT, G. C. and JURY, K. E. Effects of sex and gonadectomy on the growth and development of Southdown $\times$ Romney Cross lambs. Part II. Effects on carcass grades, measurements and chemical composition. (With One Plate and Two Text-figures)

TAYLER, J. C. and RUDMAN, J. E. The distribution of herbage at different heights in 'grazed' and 'dung patch' areas of a sward under two methods of grazing management. (With Two Text-figures) .

Pradhan, S. L., McManus, W. R., Goldstone, C. L., Hart, R. F. and Khandekar, V. N. Indices of the carcass composition of Dorset Horn top-cross lambs. III. Relationships between chemical composition, specific gravity and weight of carcasses and joints .

SmIrH, C. A. Studies on the Hyparrhenia Veld of Zambia. VII. The effects of Cattle Grazing Veld and Dambo at different stocking-rates. (With One Plate and Three Text-figures) . . . .

BiancA, W. Heat tolerance in dehydrated steers. (With Four Text-figures) . . . . . . . .

Alston, A. M. The influence of $\mathrm{N}$ and $\mathrm{Mg}$ fertilizers and $\mathrm{CaCO}_{3}$ on the absorption of $\mathrm{Mg}$ by oats. (With Six Text-figures) .

TAYLOR, St C. S. and Young, G. B. Variation in growth and efficiency in twin cattle with live weight and food intake controlled. (With Seven Text-figures)

TrAIL, J. C. M. and SACKER, G. D. Factors affecting production records of lambs from a flock of East African Blackheaded sheep

SACKER, G. D. and TraIl, J. C. M. The effect of year, suckling, dry season and type of dam (ewe or gimmer) on milk production in East African Blackheaded sheep as measured by lamb growth .

TraII, J. C. M. and SACKER, G. D. Lamb mortality in a flock of East African Blackheaded sheep .

REID, D. Studies on the cutting management of grass-clover swards. IV. The effects of close and lax cutting on the yield of herbage from swards cut at different frequencies. (With Three Text-figures)

Gallagher, J. R., WATKIN, B. R. and Grimes, R. C. An evaluation of pasture quality with young grazing sheep. I Live-weight growth and clean wool production. (With One Text-figure)

Grimes, R. C., Watkin, B. R. and Gallagher, J. R. An evaluation of pasture quality with young grazing sheep. II. Chemical composition, botanical composition and in vitro digestibility of herbage selected by oesophageal-fistulated sheep. (With Three Text-figures)

EKPETE, D. M. and CORNFIELD, A. H. Effects of varying static and changing moisture contents during incubation on ammonia and nitrate levels in soil. (With Four Text-figures)...$\quad$.

BURT, A. W. A. The nutritive value of ground and pelleted barley straw. I. Ground and pelleted versus long straw for growing Ayrshire heifers. (With One Text-figure)

BLAKEMORE, M. Seasonal changes in the amounts of phosphorus and potassium dissolved from soils by dilute calcium chloride solutions. (With Eight Text-figures)

Rogers, H. H. and LAzEnBy, A. The evaluation of grasses in micro plots . . . . . . $\quad$. 147

The Journal of Agricultural Science is issued every other month in parts of about 150 pages with plates and figures, three parts constituting a volume. Two volumes yearly.

Quotations for available back volumes and parts may be obtained on application to the Cambridge University Press.

Papers for publication should be typewritten or written in a very legible hand, and may be sent to Dr G. D. H. BeLL, Plant Breeding Institute, Maris Lane, Trumpington, Cambridge, or to the Associate Editors. Other communications should be addressed to the University Press, Cambridge.

If Plates in excess of one per 24 pages of text or coloured plates are submitted the author may be asked to bear the cost of such Plates.

The lettering on text figures should be clear of the illustration and indicating by blue pencilled lines the desired position.

Bibliography should be given in the form of 'references' in the following form:

Surname of authors (in alphabetical order), initials, date of publication (in brackets), title of Journal (abbreviated according to the World list of Scientific Periodicals), volume and page of reference. In the text a reference should be quoted by the author's name and date (in brackets).

All names of Journals and books are set in italics; they should be indicated on the typescript by underlining.

Contributors will receive twenty-five copies of their papers free.

The subscription price, payable in advance, is $75 s$. net per volume (post free); single numbers $32 s .6 d$. net. Subscriptions may be sent to any bookseller, or to The Cambridge University Press, Bentley House, 200 Euston Road, London, N.W. 1.

Subscription price in the U.S.A. is $\$ 13.50$ per volume; single numbers $\$ 5.50$. Enquiries should be addressed to the Cambridge University Press, American Branch, 32 East 57th Street, New York, N.Y. 10022. 